\title{
Determination of $\mathbf{T}$ Cell Responses in Thai Systemic Sclerosis Patients
}

\author{
Oranit Likhit, ${ }^{1}$ Worawit Louthrenoo, ${ }^{2}$ Sa-nga Pattanakitsakul, ${ }^{3}$ \\ Aroonroong Suttitheptumrong, ${ }^{3}$ Supot Hannongbua, ${ }^{4}$ Thanyada Rungrotmongkol, ${ }^{5,6}$ \\ Hiroshi Noguchi, ${ }^{7,8}$ Fujio Takeuchi, ${ }^{8}$ and Kobporn Boonnak $\mathbb{D}^{9}$
}

\footnotetext{
${ }^{1}$ Department of Microbiology and Immunology, Faculty of Tropical Medicine, Mahidol University, Bangkok 10400, Thailand ${ }^{2}$ Division of Rheumatology, Department of Internal Medicine, Faculty of Medicine, Chiang Mai University, 50200, Thailand

${ }^{3}$ Division of Molecular Medicine, Research Department, Faculty of Medicine Siriraj Hospital, Mahidol University, Bangkok 10700, Thailand

${ }^{4}$ The Center of Excellence in Computational Chemistry, Department of Chemistry, Faculty of Science, Chulalongkorn University, Bangkok 10330, Thailand

${ }^{5}$ Biocatalyst and Environmental Biotechnology Research Unit, Department of Biochemistry, Faculty of Science, Chulalongkorn University, Bangkok 10330, Thailand

${ }^{6}$ Program in Bioinformatics and Computational Biology, Graduate School, Chulalongkorn University, Bangkok 10330, Thailand

${ }^{7}$ School of Pharmacy, Nihon Pharmaceutical University, Saitama 361-0806, Japan

${ }^{8}$ School of Pharmaceutical Science, University of Shizuoka, Shizuoka 422-8526, Japan

${ }^{9}$ Department of Immunology, Faculty of Medicine Siriraj Hospital, Mahidol University, Bangkok 10700, Thailand
}

Correspondence should be addressed to Kobporn Boonnak; kobporn.boo@mahidol.edu

Received 10 December 2021; Revised 12 February 2022; Accepted 21 February 2022; Published 7 March 2022

Academic Editor: Baohui Xu

Copyright (C) 2022 Oranit Likhit et al. This is an open access article distributed under the Creative Commons Attribution License, which permits unrestricted use, distribution, and reproduction in any medium, provided the original work is properly cited.

Objectives. This study is aimed at determining the role of T cells by assessing the numbers of IFN- $\gamma$ - and IL-2-secreting T cells following stimulation with peptides derived from DNA topoisomerase-I protein in Thai SSc patients. Methods. Fifty Thai SSc patients and 50 healthy controls (HC) joined this study. IFN- $\gamma$ and IL-2 levels upon stimulation of T cells with 6 peptides derived from DNA topoisomerase-I protein were determined. Anti-nuclear antibodies (ANA) and anti-Scl-70 antibodies were determined by using the ELISA method. Results. In SSc patients, we detected a significantly higher number of IFN- $\gamma$ - and IL2-secreting $\mathrm{CD}^{+} \mathrm{T}$ cells than IFN- $\gamma$ - and IL-2-secreting $\mathrm{CD} 4^{+} \mathrm{T}$ cells after stimulation with pooled peptides derived from DNA topoisomerase-I protein. A similar percentage of $\mathrm{CD} 4^{+} \mathrm{IL}-2^{+}, \mathrm{CD} 4^{+} \mathrm{IFN}-\gamma^{+}$, and $\mathrm{CD} 8{ }^{+} \mathrm{IL}-2^{+}$were detected following stimulation with DNA topoisomerase-I protein -in SSc patients with anti-Scl-70 antibody (SSc/anti-Scl-70 ${ }^{+}$) and those without. In contrast, the amount of $\mathrm{CD}^{+} \mathrm{IFN}-\gamma^{+}$cells was significantly higher in SSc/anti-Scl- $70^{+}$than those without. Stimulation with individual peptides showed that CSLRVEHINLHPELD (sPep3; 15 amino acids; position 505-519 of DNA topoisomerase-I protein) was the optimal epitope that induced $\mathrm{T}$ cells secreting the highest levels of IFN- $\gamma$ and IL-2. A higher percentage of IFN $-\gamma^{+} \mathrm{CD} 4^{+} \mathrm{T}$ cells was detected in SSc/anti-Scl- $70^{+}$than those without the following stimulation with peptides 2 (amino acid position 475-486 [RAVALYFIDKLA] of protein DNA topoisomerase). Conclusion. The results from this study emphasize the critical role of DNA topoisomerase-I peptides on the activation of $\mathrm{T}$ cells in SSc patients. The findings provide a better understanding of SSc's immunopathogenesis and may lead to the development of diagnostic tools and specific treatments for SSc in the future. 


\section{Introduction}

Systemic sclerosis (SSc), or scleroderma, is a chronic autoimmune inflammatory disease characterized by extensive tissue fibrosis and various vascular complications. The etiology of SSc remains unknown, but genetics, environmental factors, and immunological abnormalities have been found to contribute to the development of the disease. Among these factors, the immunological factors have been intensively studied. For instance, the presence of SSc-specific autoantibodies is commonly associated with the pathogenesis of SSc $[1,2]$. Among these autoantibodies, antitopoisomerase has been reported to precede the development of overt clinical disease SSc patients $[3,4]$. There are 2 types of SScs: limited cutaneous SSc (lcSSc) and diffuse cutaneous SSc (dcSSc) [5]. lcSSc patients usually have anti-centromere antibodies (ACA) and often present with pulmonary arterial hypertension, whereas dcSSc patients usually present with extensive skin involvement, cardiac involvement, and pulmonary fibrosis often associated with anti-topoisomerase-I autoantibodies (anti-Scl-70) [6]. Despite these robust associations, the level of serum anti-Scl-70 is not useful to monitor disease progression in SSc patients. Moreover, several studies also suggest that $\mathrm{T}$ cells play a vital role as a contribution factor for the development of SSc. For instance, the impairment of $\mathrm{CD} 4^{+} \mathrm{T}$ cell and regulatory $\mathrm{T}$ cell (Treg) function has been reported in SSc patients $[7,8]$. High levels of $\mathrm{CD}^{+} \mathrm{T}$ cells were reported in a SSc patient's blood [9] and bronchoalveolar lavage fluid from SSc patients with lung fibrosis, suggesting the $\mathrm{CD} 8^{+} \mathrm{T}$ cells may play a critical role in the pathogenesis of SSc disease [10]. However, the explicit role of the $\mathrm{CD}^{+} \mathrm{T}$ cells on immunopathogenesis of SSc has not been intensively studied. Importantly, anti-DNA topoisomerase antibodies (anti-Scl-70) exhibit a strong association with human leukocyte antigen (HLA) alleles across different ethnic groups, suggesting the involvement of $\mathrm{T}$ cells in the autoantibody development $[11,12]$. In this context, the identification of immunodominant $\mathrm{T}$ cell epitopes of the DNA topoisomerase-I protein is of particular relevance. The presence of $\mathrm{T}$ cells specific to DNA topoisomerase-I proteins has been investigated in SSc patients in several countries such as America, Europe, Korea, and Japan [13, 14]. There is limited data on $T$ cell responses in SSc patients in Southeast Asia, including Thailand. Here, we studied T cell activation in Thai SSc patients by measuring the IFN$\gamma$ - and IL-2-secreting $\mathrm{CD}^{+}$and $\mathrm{CD}^{+} \mathrm{T}$ cells following stimulation with peptides derived from DNA topoisomerase-I protein [14]; the protein that has been reported to be related to anti-Scl-70 autoantibodies.

\section{Materials and Methods}

2.1. Patients and Healthy Volunteers. Fifty SSc patients who were followed up at the Division of Rheumatology, Department of Internal Medicine, Faculty of Medicine, Chiang Mai University, were included in the study. All SSc patients were diagnosed according to the 1980 American College of Rheumatology classification criteria for the diagnosis of systemic sclerosis [15]. The severity of skin involvement was determined by the Modified Rodnan Skin Score (MRSS) [16]. The fifty healthy volunteers used as control were medical personnel who did not have any evidence of autoimmune disease.

Approximately $20 \mathrm{~mL}$ of whole blood sample was collected in EDTA blood collection tubes from the SSc patients and healthy volunteers. The blood samples were transferred from Chiang Mai University to the Department of Microbiology and Immunology, Faculty of Tropical Medicine, Mahidol University, within 24 hours while being stored at $4-8^{\circ} \mathrm{C}$.

2.2. PBMCs Isolation from Whole Blood Samples. PBMCs were isolated as previously described [17]. Briefly, whole blood samples were diluted 1:1 in PBS or RPMI 1640 medium (Life Technologies, Grand Island, NY) and layered over Ficoll-hypaque (Sigma-Aldrich, St. Louis, MO). The PBMC were washed repeatedly with PBS at lower $g$ forces to remove platelets. The PBMC were then frozen in fetal bovine serum (FBS) (Life Technologies) supplemented with $10 \%$ dimethyl sulfoxide (Sigma-Aldrich). They were frozen at $-80^{\circ} \mathrm{C}$ overnight and then transferred to the vapor phase of liquid nitrogen the next day. Before use, the cells were rapidly thawed at $37^{\circ} \mathrm{C}$ in complete medium (RPMI supplemented with $10 \%$ FBS, 2 mM-glutamine and $1 \mathrm{X}$ anti-anti (Life Technologies)). The cells were gently pelleted and resuspended with complete media for further use.

\subsection{Candidate Peptides Derived from DNA Topoisomerase-I} Protein. Six peptides were designed based on potential T cell epitopes of protein DNA topoisomerase-I (Scl 70) [12]. All 6 synthetic peptides were purchased from GenScript Japan Co. (Tokyo, Japan). The brief description and amino acid position of these six peptides are SPep1: NCSKDAKVPSPP (385-396), SPep2: RAVALYFIDKLA (475-486), SPep3: CSLRVEHINLHPELD (505-519), SPep4: KVVESKKKAVQRLEE (682-696), SPep5: PIEKIYNKTQREKFA (739-753), and SPep7: KFAWAIDMADED (751-762). These peptides have successfully stimulated $\mathrm{T}$ cells isolated from North American Caucasians, North American Blacks, and Japanese SSc patients in a previous study [12]. Therefore, we selected those peptides for testing in Thai SSc patients. A peptide Npep1 (LKRRIMPEDIIINCS) has been used as a control peptide. This peptide did not stimulate $\mathrm{T}$ cell responses in SSc patients and healthy volunteers similar to media control. Therefore, we used media control as a negative control for all experiments (Supplement Figure 1).

2.4. Antigen Stimulation and Intracellular Cytokine Staining (ICS). Antigen stimulation and ICS were performed as previously described with some modification $[18,19]$. $1 \times 10^{6}$ PBMCs were stimulated with complete media containing $50 \mu \mathrm{g} / \mathrm{ml}$ PMA and $250 \mathrm{ng} / \mathrm{ml}$ Ionomycin or $10 \mu \mathrm{g} / \mathrm{ml}$ pooled peptides or $10 \mu \mathrm{g} / \mathrm{ml}$ of individual peptides for 24 hours at $37^{\circ} \mathrm{C}$ in an incubator containing $5 \% \mathrm{CO}_{2}$ and $5 \%$ humidity. During the last 16 hours of culture, $2 \mu \mathrm{l}$ of Golgistop $^{\mathrm{TM}}$ (BD Biosciences, San Diego, CA) containing monensin (Biolegend, San Diego, CA) was added to block cytokine secretion. Cells were surface stained with anti- 
CD3-APC, anti- CD4-FITC, and anti-CD8 PerCP (BD Biosciences) for 30 minutes at $4^{\circ} \mathrm{C}$. Following permeabilization, these cells were then stained with anti-human IFN- $\gamma$ and IL2 (BD Biosciences) for 30 minutes at $4^{\circ} \mathrm{C}$. Cells were finally resuspended with $200 \mu \mathrm{l}$ of $2 \%$ paraformaldehyde (SigmaAldrich) and analyzed by Facscalibur (BD Biosciences). Data was analyzed using the CellQuest Pro software (BD Biosciences) and FlowJo 10.8.1 software (TreeStar, Ashland OR, USA). Gating is shown in supplementary Figure 1.

2.5. Ethical Statements. This study was approved by the ethical committee of the Faculty of Tropical Medicine, Mahidol University, Thailand (approval number: MUTM 2018-042-01); the ethical committee of Faculty of Medicine, Chiang Mai University, Thailand (approval number: MED-2559-04370/4370); and the ethical committee of Tokyo Seiei College, Japan (approval number: 20160004 and 20190006). All participants provided their written informed consent prior to entering the study.

2.6. Statistical Analysis. The normality of distribution of cytokine secretion levels were determined using Student's paired $t$-test. Summary statistic is expressed as median values. Data was analyzed using the GraphPad Prism software version 9.0 (GraphPad Software, Sam Diego, CA). Continuous variables were presented as mean \pm standard deviation (SD) or median (min-max), while categorical variables were presented as frequency and percentage. To determine the difference between two independent samples of continuous variables, the Student $t$-test was used for variables with normal distribution and the Wilcoxon rank sum test for nonnormal distribution. A $p$ value of less than 0.05 was considered statistically significant.

\section{Results}

3.1. Participant Demographic Data. There were 50 SSc patients (10 male and 40 female) who had a mean \pm SD age of $50.4 \pm 11.1$ years, with the MRSS score ranging from 2 to 31 (median 7). There were 28 patients (56\%) with dcSSc and 22 patients (44\%) with lcSSc. Antinuclear antibody, anti-centromere antibody, and anti-topoisomerase antibody (anti-Scl70) presented in 50 (100\%), 8 (16\%), and $34(68 \%)$ patients, respectively. The clinical manifestation of SSc was Raynaud's phenomenon in all (100\%), lung involvement in $42(84 \%)$, digital pitting scars in $27(57 \%)$, dysphagia in 28 (56\%), arthritis in 24 (48\%), sclerodactyly in $23(46 \%)$, telangiectasia in $22(44 \%)$, and myositis in $3(6 \%)$ patients. Family of SSc was documented in 3 patients (6\%). For the control volunteers, 50 healthy volunteers ( 38 female and 12 male) who had a mean \pm SD age of $58.9 \pm 9.8$ years were enrolled in the study. Among these healthy volunteers, antinuclear antibodies (ANA) were detected in $5(10 \%)$ individuals.

3.2. Increasing Number of IL-2- and IFN- $\gamma$-Secreting T Cells following Stimulation with Pooled Peptides Derived from DNA Topoisomerase-I Protein in SSc Patients. To determine $\mathrm{T}$ cell responses, the PBMCs from SSc patients were stimulated with $10 \mu \mathrm{g} / \mathrm{ml}$ pooled peptides derived from topoisomerase protein (Scl-70 protein) for 24 hours. The combination of $250 \mathrm{ng} / \mathrm{ml}$ ionomycin and $50 \mu \mathrm{g} / \mathrm{ml}$ PMA was used as a positive control stimulus in all experiments. We tested the $\mathrm{T}$ cell responses to other nonspecific peptide and found a similar degree of cytokine production as stimulated with media control (Supplementary Figure 2). Therefore, we used media control as a negative control for the following experiments. Following stimulation with the pooled peptides, we found increased numbers of IL-2 and IFN- $\gamma$ secreting $\mathrm{CD}^{+}$and $\mathrm{CD}^{+} \mathrm{T}$ cells in the PBMCs isolated from SSc patients but not in healthy volunteers. Moreover, both $\mathrm{CD}^{+}$and $\mathrm{CD}^{+}{ }^{+} \mathrm{T}$ cells from SSc patients responded to the PMA/ionomycin by secreting IL- 2 and IFN- $\gamma$ better than those detected in healthy volunteers (Figure 1).

We hypothesize that the level of anti-Scl-70 detected in SSc patient's serum is influenced by Scl-70 protein-specific T cells. Therefore, we determined whether the presence of antiScl-70 antibody is associated with the degree of cytokine production by $\mathrm{T}$ cells by stimulation with either PMA/ionomycin or pooled peptides derived from DNA topoisomerase-I protein. The results showed that a similar percentage of $\mathrm{CD} 4^{+-}$ $\mathrm{IL}-2^{+}, \mathrm{CD} 4^{+} \mathrm{IFN}-\gamma^{+}$, and $\mathrm{CD} 8^{+} \mathrm{IL}-2^{+} \mathrm{T}$ cells was detected in SSc patients with and without anti-Scl-70 antibody following stimulation with peptides derived from Scl-70 protein (Figures 2(a)-2(c)). Interestingly, the amount of $\mathrm{CD}^{+}$IFN$\gamma^{+}$T cells was significantly higher in SSc patients with antiScl-70 antibody (Figure 2(d)) following stimulation with pooled peptides but not with PMA ionomycin. This result suggests that the presence of Scl-70 antibodies may be related to the production of IFN- $\gamma$ by T cells and vice versa.

To exclude the possibility that the numbers of $\mathrm{T}$ cells were different among SSc patients and healthy volunteers; which may contribute to the difference in the percentage of the cytokine-producing $\mathrm{T}$ cells. The enumeration of $\mathrm{CD} 4^{+}$ and $\mathrm{CD}^{+} \mathrm{T}$ cells was performed by flow cytometry in both SSc patients and healthy volunteers in all conditions tested in this study. Both groups showed a similar percentage of $\mathrm{CD}^{+}$and $\mathrm{CD}^{+} \mathrm{T}$ cells (approximately $30 \%$, mean $\pm \mathrm{SD}=$ $29.55 \pm 9.29$ ) (Figure 3), regardless of the experiment condition. This data indicated that the percentage of IFN $-\gamma^{+}$and IL- ${ }^{+}$secreted from $\mathrm{T}$ cells observed in subsequent experiments was not a result of differences in the percentage of $\mathrm{CD}^{+}$and $\mathrm{CD}^{+}{ }^{+} \mathrm{T}$ cells among SSc patients with and without anti-Scl-70 antibody and healthy volunteers.

3.3. Similar T Cell Responses Were Observed in dcSSc and lcSSc. In order to explore the difference in T cell responses in patients with dcSSc and lcSSC, the percentage of cytokine secreting $\mathrm{CD}^{+}$and $\mathrm{CD}^{+}{ }^{+} \mathrm{T}$ cells in these two groups were compared. The percentage of $\mathrm{CD} 4^{+} \mathrm{IFN}-\gamma^{+}-, \mathrm{CD}^{+} \mathrm{IL}-2^{+}-$, $\mathrm{CD} 8^{+} \mathrm{IFN}-\gamma^{+}$-, and $\mathrm{CD} 8^{+} \mathrm{IL}_{-} 2^{+}$-secreting cells was similar between dcSSc and lcSSc patients following stimulation with positive control stimulus and pooled peptides from DNA topoisomerase-I protein. No significant difference in $\mathrm{T}$ cell responses among these two groups was observed (Figure 4). Therefore, the level of IFN- $\gamma$ and IL-2 production by T cells is not directly associated with the type of SSc disease.

3.4. High Levels of IFN- $\gamma$ and IL-2 Expression Were Observed from the $\mathrm{CD}^{+} \mathrm{T}$ Cells of SSC Patient with Anti-SCl-70 Antibody. Expression of IFN- $\gamma$ and IL-2 by $\mathrm{CD}^{+}$and 


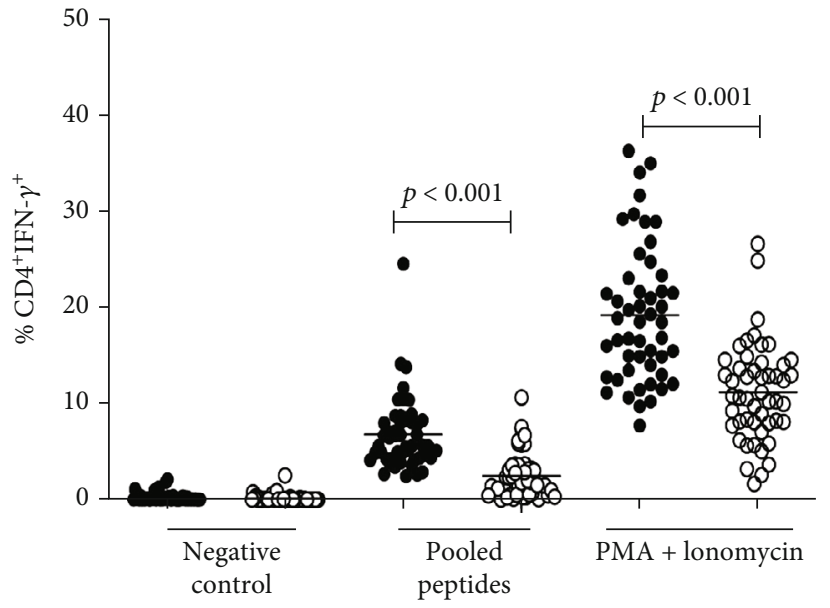

SSc patients Healthy volunteers

(a)

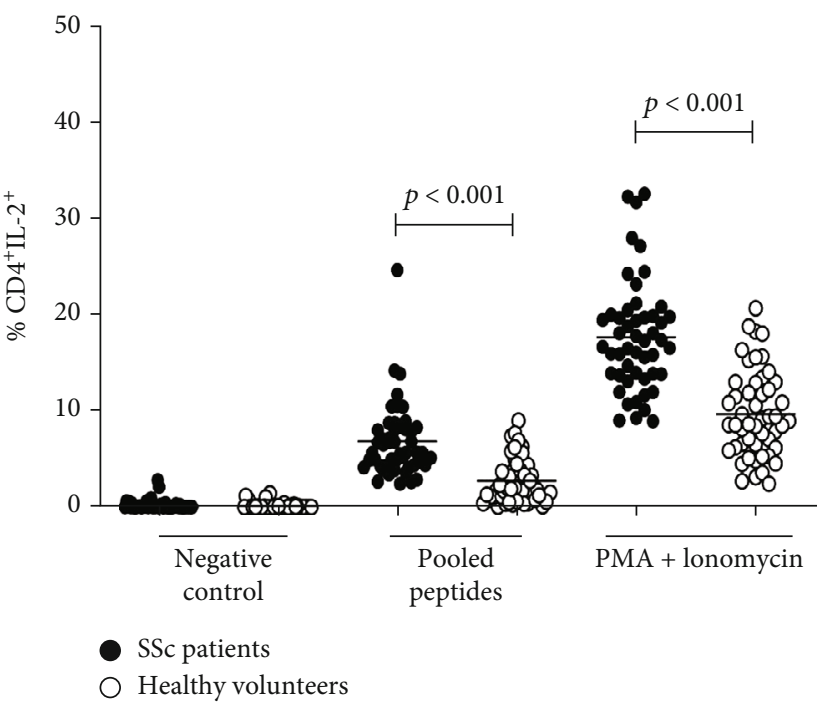

(c)

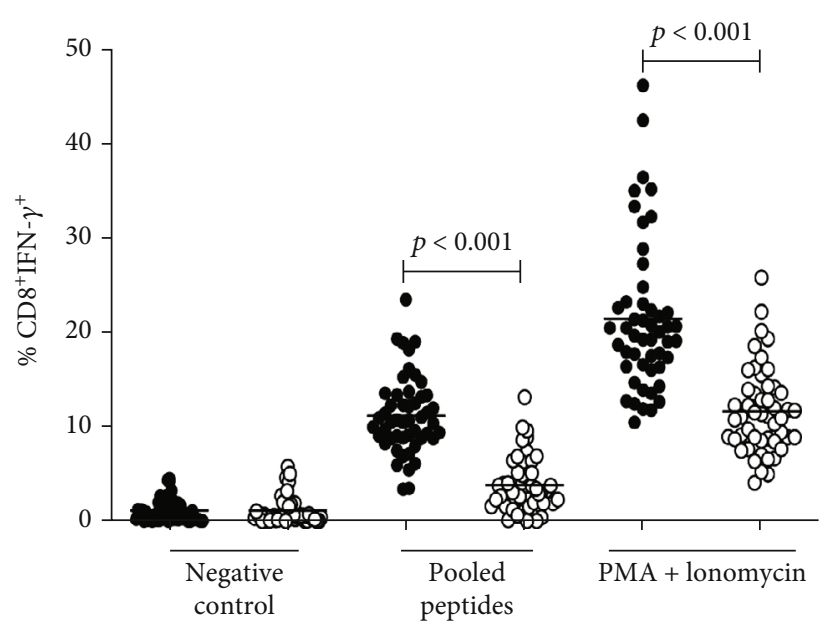

- SSc patients

O Healthy volunteers

(b)

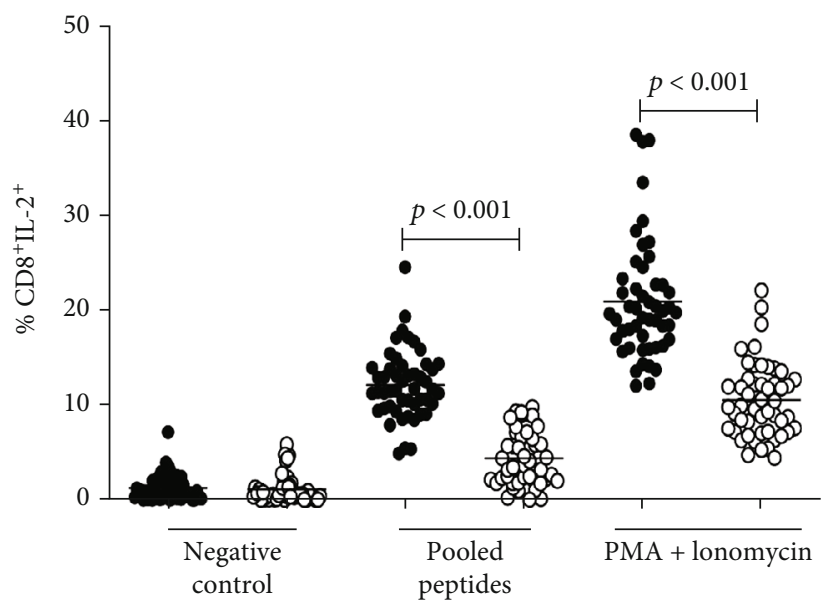

SSc patients

O Healthy volunteers

(d)

Figure 1: Percentage of cytokines (IFN- $\gamma$ and IL-2) producing $\mathrm{CD}^{+}(\mathrm{a}, \mathrm{c})$ and $\mathrm{CD}^{+}(\mathrm{b}, \mathrm{d}) \mathrm{T}$ cells following stimulation with media (negative control), pooled peptides derived from DNA topoisomerase-I protein, and PMA ionomycin (positive control) in SSc patients $(n=50)$ and healthy volunteers $(n=50)$ (Student's $t$-test, $p$ value $<0.001)$.

$\mathrm{CD}^{+} \mathrm{T}$ cells following stimulation with pooled peptides was determined. Mean fluorescence intensity (MFI) was used to quantify $\mathrm{CD}^{+}$and $\mathrm{CD} 8^{+} \mathrm{T}$ cells which stained positive for IFN- $\gamma$ and IL-2. The MFI of IFN- $\gamma$ and IL- 2 was similar in $\mathrm{CD}^{+} \mathrm{T}$ cells from anti-Scl-70 positive and negative SSc patients (IFN- $\gamma ; 312.4 \pm 54.29$ vs $285.60 \pm 56.27$ and IL-2; $314.70 \pm 76.34$ vs $285.60 \pm 56.27)$. In contrast, the MFI of IFN- $\gamma$ and IL-2 was significantly higher in $\mathrm{CD} 8^{+} \mathrm{T}$ cells of SSc patients with anti-Scl-70 antibody than that in patients without anti-Scl-70 antibody (IFN- $\gamma ; 357.00 \pm 43.6$ vs $303.00 \pm 38.70 ; p<0.001$ and IL-2; $356.60 \pm 44.71$ vs $314.30 \pm 44.73 ; p<0.01$ ) (Figure 5).

3.5. IFN- $\gamma$ and IL-2 Secreting $C D 4^{+}$and $C D 8^{+} T$ Cells following Stimulation with Individual Peptides Derived from
DNA Topoisomerase-I Protein. To further identify the specific epitopes among these six peptides derived from DNA topoisomerase-I protein, the available PBMCs isolated from 23 SSc patients with anti-Scl-70 antibody and 9 SSc patients without anti-Scl-70 antibody were stimulated with individual peptides at the concentration of $10 \mu \mathrm{g} / \mathrm{ml}$ for 24 hours. The percentage of IFN- $\gamma$ - and IL-2-secreting T cells was determined by flow cytometry. The results revealed higher percentage of IFN- $\gamma$ and IL-2 secreting $\mathrm{CD}^{+} \mathrm{T}$ cells than that observed in $\mathrm{CD}^{+} \mathrm{T}$ cells following stimulation with individual peptides (Figures 6(a)-6(d)). Interestingly, higher number of IFN- $\gamma^{+} \mathrm{CD} 4^{+} \mathrm{T}$ cells isolated from SSc patients who were anti-Scl-70 antibody negative was observed than that in $\mathrm{CD}^{+} \mathrm{T}$ cells from SSc patients with anti-Scl-70 


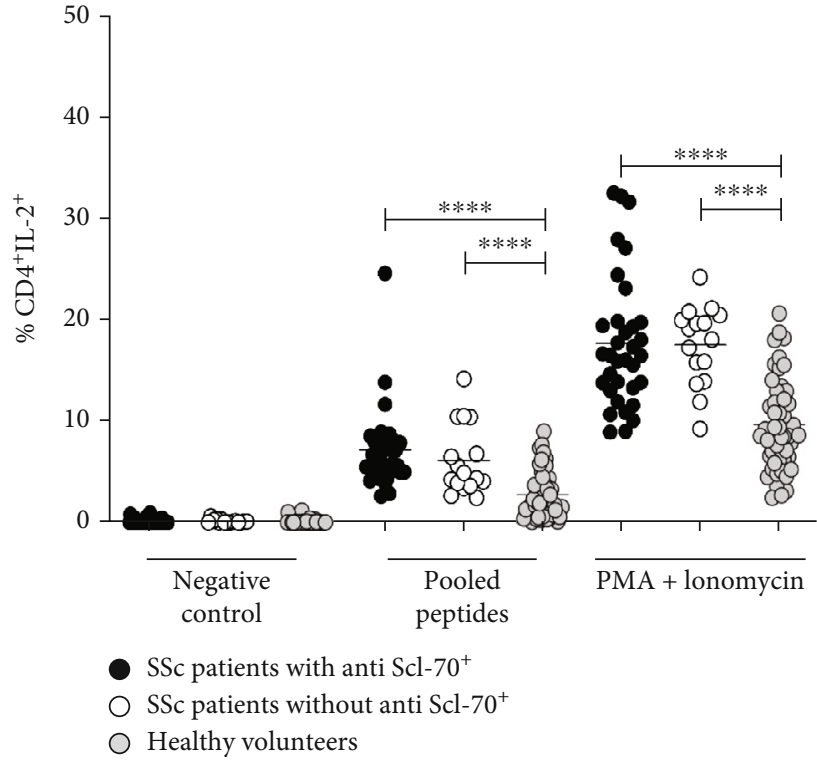

(a)

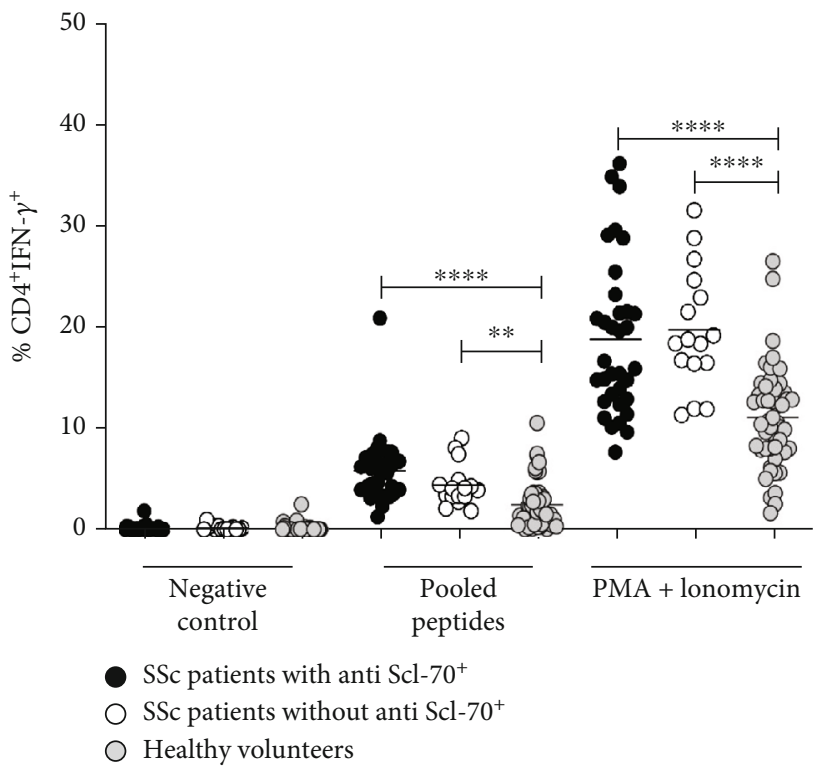

(c)

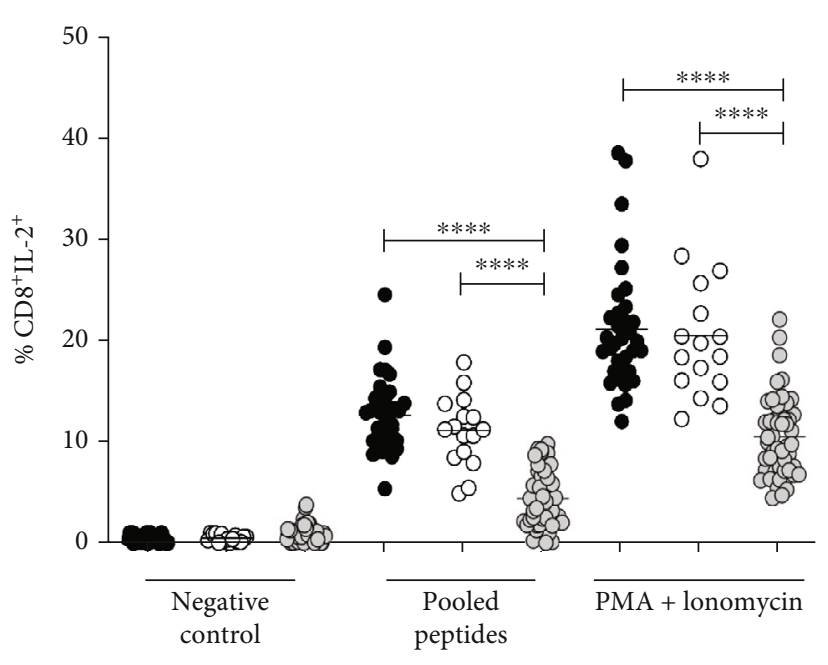

- SSc patients with anti Scl- $70^{+}$

SSc patients without anti Scl- $70^{+}$

Healthy volunteers

(b)

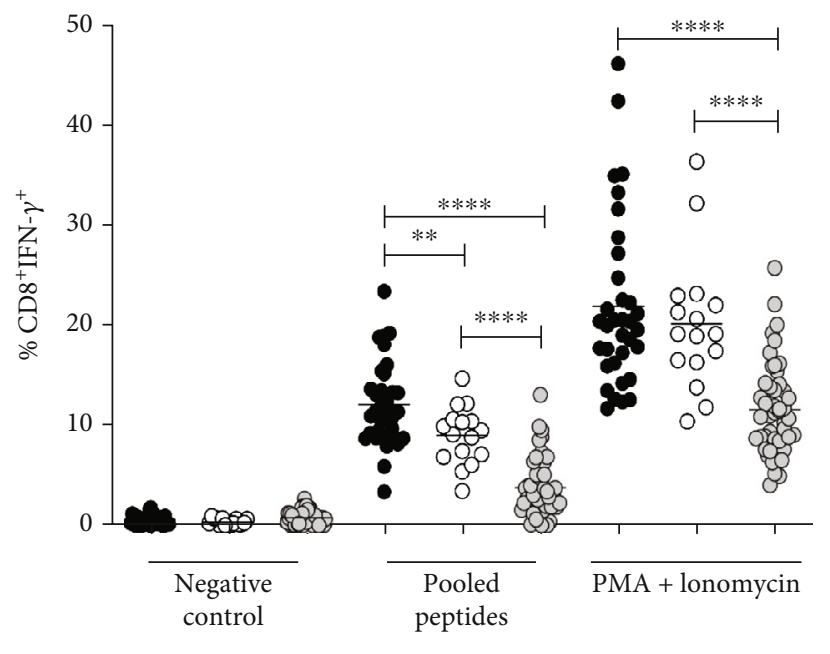

- SSc patients with anti Scl-70

O SSc patients without anti Scl- $70^{+}$

Healthy volunteers

(d)

FIgure 2: Percentage of cytokine (IFN- $\gamma$ and IL-2) producing $\mathrm{CD}^{+}(\mathrm{a}, \mathrm{c})$ and $\mathrm{CD}^{+}(\mathrm{b}, \mathrm{d}) \mathrm{T}$ cells following stimulation with media (negative control), pooled peptides derived from topoisomerase protein, and PMA ionomycin (positive control) in SSc patients with positive anti-Scl70 antibodies $(n=34)$ and SSc patients with negative anti-Scl70 antibodies $(n=16)$ (Student's $t$-test, $* * * * p$ value $<$ $0.001, * * p$ value $<0.05)$.

antibody following stimulation with peptides 2, which corresponds to amino acid position 475-486 (RAVALYFIDKLA) of protein DNA topoisomerase-I (Figure 6(a)). We did not observe a significant difference in the percentage of IL-2 producing $\mathrm{CD}^{+} \mathrm{T}$ cell between these two groups. Although high numbers of IL- $2^{+} \mathrm{CD} 8^{+}$and IFN $-\gamma^{+} \mathrm{CD} 8^{+} \mathrm{T}$ cells were observed in SSc patients, there was no significant difference in the levels of these cells in SSc patients with or without anti-Scl-70 antibody.

\section{Discussion}

Although the role of $\mathrm{T}$ cells in the development of systemic sclerosis has long been recognized, the mechanisms responsible for the initiation of $\mathrm{T}$ cells responses in the pathogenesis of SSc remain insufficiently understood. Here, we demonstrated the effect of DNA topoisomerase-I protein on $\mathrm{T}$ cell activation in Thai SSc patients. The DNA topoisomerase-I protein was chosen because it has been 


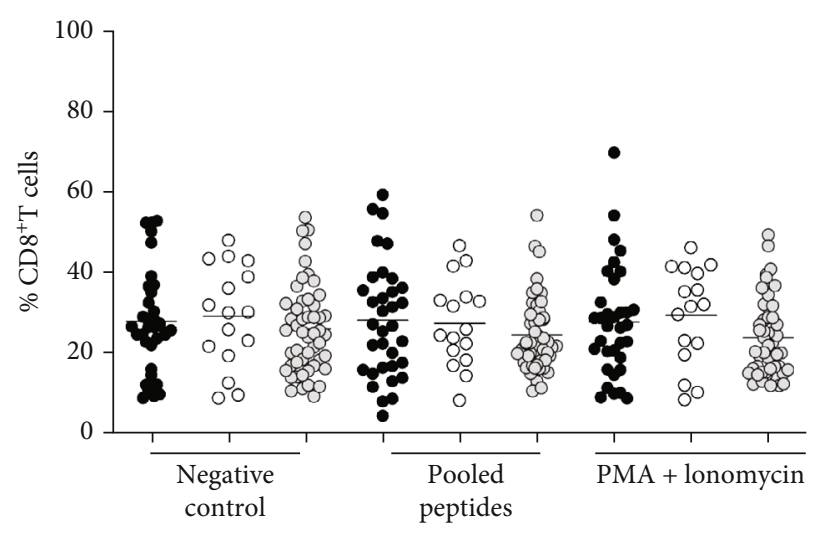

SSc patients with anti Scl-70

SSc patients without anti Scl- $70^{+}$

Healthy volunteers

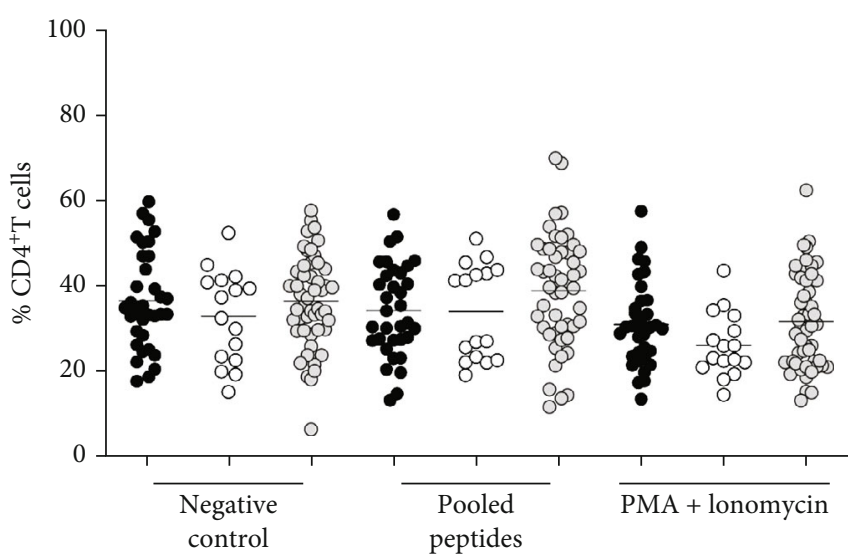

SSc patients with anti Scl-70 $0^{+}$

SSc patients without anti Scl- $70^{+}$

Healthy volunteers

(a)

(b)

Figure 3: The number of $\mathrm{CD}^{+}(\mathrm{a})$ and $\mathrm{CD}^{+}(\mathrm{b}) \mathrm{T}$ cells in SSc patients $(n=50)$ and healthy volunteers $(n=50)$.

shown to affect immune activation in SSc patients [12]. Since $\mathrm{T}$ cells are necessary for the production of antitopoisomerase-I antibodies in SSc patients [12], we sought to determine the $\mathrm{T}$ cell responses following stimulation with peptides derived from DNA topoisomerase-I proteins in Thai SSc patients with and without anti-Scl-70 antibodies. In this study, we focus on IFN- $\gamma$ and IL- 2 secreting CD $4^{+}$ and $\mathrm{CD}^{+} \mathrm{T}$ cells because high levels of IFN- $\gamma$ have been observed in SSc patient's plasma samples [20, 21]. Additionally, IL-2 is involved in the proliferation of T cells and affects several immunological pathways [22]. However, the controversy of IL-2 levels in SSc patient serums has long been recognized [5, 23-25]. This might be due to different disease status in the same patient and different population study groups. Moreover, genetic alteration of IL-2 gene has been proposed as a marker for the limited phenotype of SSc [26].

Although the association of anti-Scl-70 antibody and the presence of topoisomerase-I ( $\mathrm{Scl}-70)$ specific $\mathrm{CD} 4^{+} \mathrm{T}$ cells in SSc patients has been reported [27], we found that following stimulation by peptides derived from DNA topoisomerase protein, the numbers of IFN- $\gamma$ and IL-2 secreting $\mathrm{CD}^{+} \mathrm{T}$ cells was comparable in SSc patients with and without anti-Scl-70 antibodies. This might be due to a different antigen used to activate PBMCs and/or use of different study populations. In regards to the activation of $\mathrm{CD}^{+} \mathrm{T}$ cells, a higher percentage of IFN- $\gamma$ secreting $\mathrm{CD}^{+} \mathrm{T}$ cells was observed in SSc patients with anti-Scl-70 antibodies following stimulation with peptides derived from DNA topoisomerase-I. On the other hand, similar levels of IL-2 secreting $\mathrm{CD}^{+} \mathrm{T}$ cells were observed in both groups. However, conflicting results have been reported so far as some studies found that PHA stimulated PBMCs from SSc patients produced less IFN- $\gamma$ than the control group [24, 28] whereas a study from Italy showed increased levels of IFN- $\gamma$ mRNA in the peripheral blood of SSc patients following PMA stimulation when compared to healthy controls [29]. In agreement with other studies investigating the cyto- kine production following stimulation with PMA and ionomycin [28-30], we also found that T cells isolated from SSc patients secreted IFN- $\gamma$ and IL- 2 better than the T cells isolated from healthy volunteers. Increased levels of interferon (IFN) regulated genes such as Siglec 1 and $M X 1$ have been reported in monocytes isolated from lcSSc patients, especially lcSSc associated with pulmonary arterial hypertension [31]. However, we observed a similar percentage of IFN- $\gamma$ secreting T cells between lcSSc and dcSSc patients following stimulation with DNA topoisomerase-I peptide. The discrepancy may be caused by different cell types and antigens used in the assay. The contribution of IFN- $\gamma$ as biomarkers for SSc to distinguish different types of SSc patients warrants further research. Our results indicated that IFN- $\gamma$ and IL-2 were predominantly secreted by $\mathrm{CD}^{+} \mathrm{T}$ cells in SSc patients and healthy volunteers following stimulation with DNA topoisomerase-I peptides or control antigen. We therefore speculate that these antigens might be potent activators for $\mathrm{CD}^{+} \mathrm{T}$ cells, but the activation mechanism needs to be further studied.

We found that peptide 3 (Spep3, CSLRVEHINLHPELD; length 15 amino acids; amino-acid position 505-519 of DNA topoisomerase protein), followed by peptides 2 and 4 , efficiently stimulated $\mathrm{CD}^{+}$and $\mathrm{CD}^{+} \mathrm{T}$ cells of SSc patients. Interestingly, stimulation with peptide 2 , which corresponds to amino acid position 475-486 (RAVALYFIDKLA) of DNA topoisomerase-I protein, induced a higher percentage of IFN- $\gamma$ secreting $\mathrm{CD}^{+}{ }^{+} \mathrm{T}$ cells in SSc patients without antiScl-70 antibody than that observed in patients with antiScl-70 antibodies. This effect has not been detected by stimulation with other individual peptides, suggesting that this peptide may contribute to $\mathrm{T}$ cell responses in the SSc patients. However, further studies need to be conducted to understand the biological function of peptide 2. Majority of the peptides used in our study were between 12-15 amino acids long. Theoretically, this length is suitable for MHC class II processing and activation of $\mathrm{CD}^{+} \mathrm{T}$ cells. Peptides 


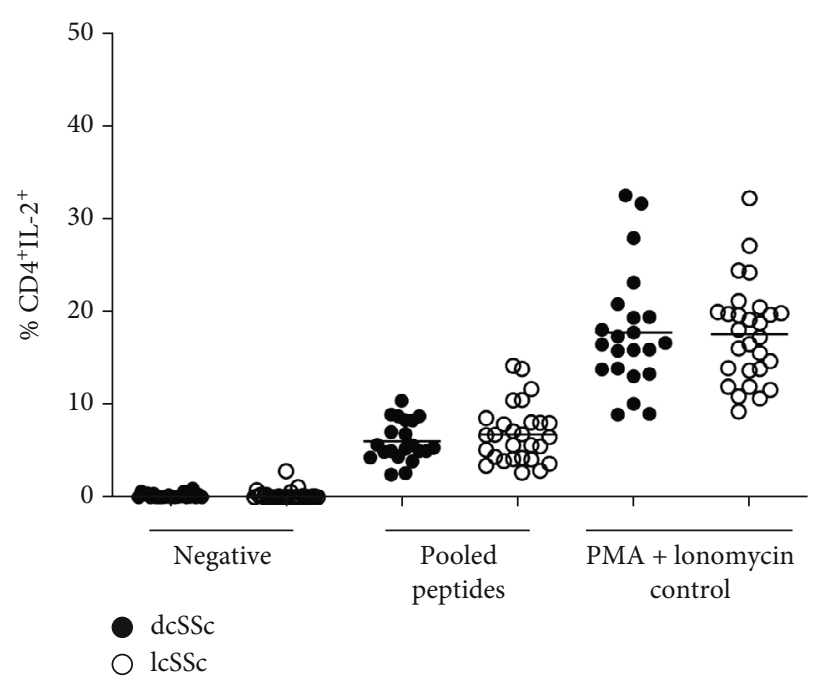

(a)

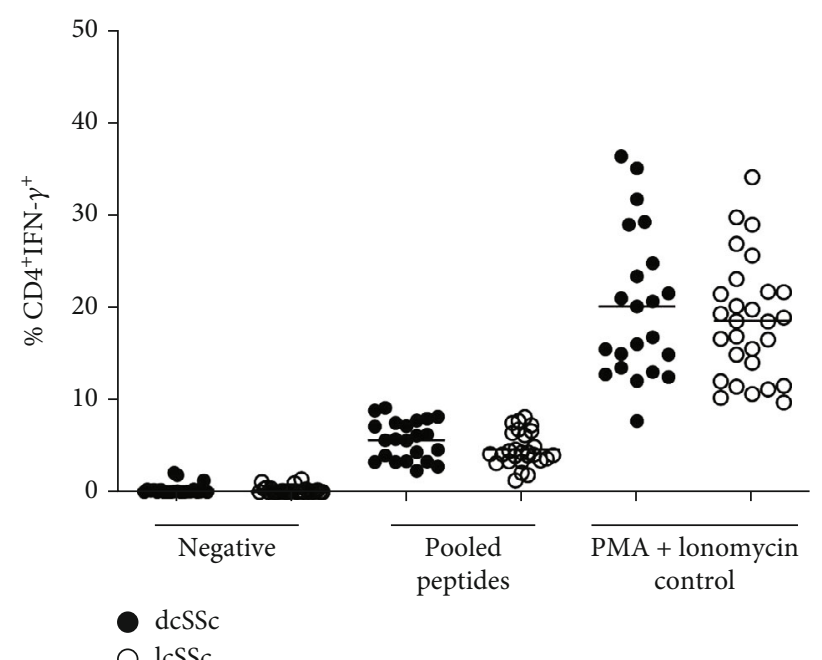

(c)

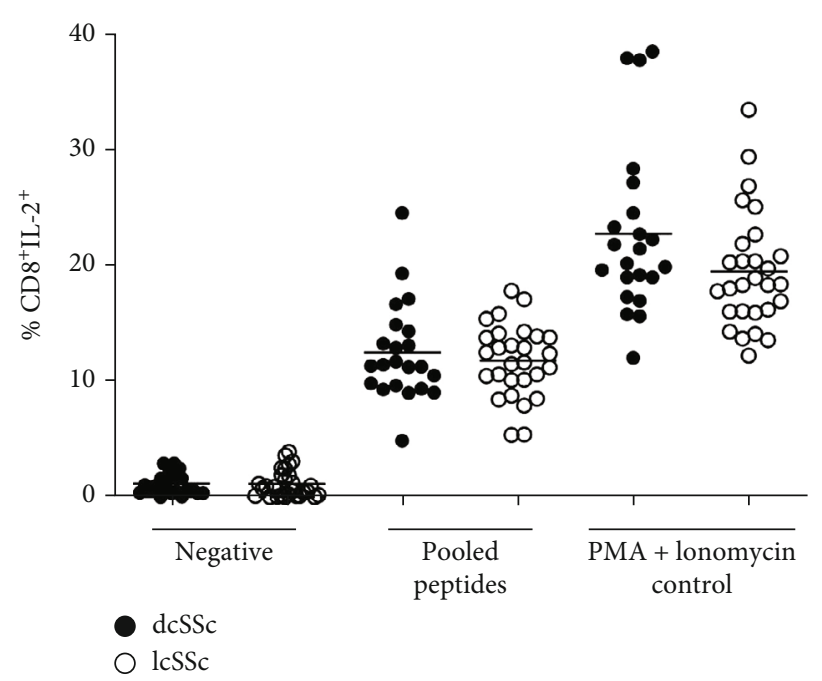

(b)

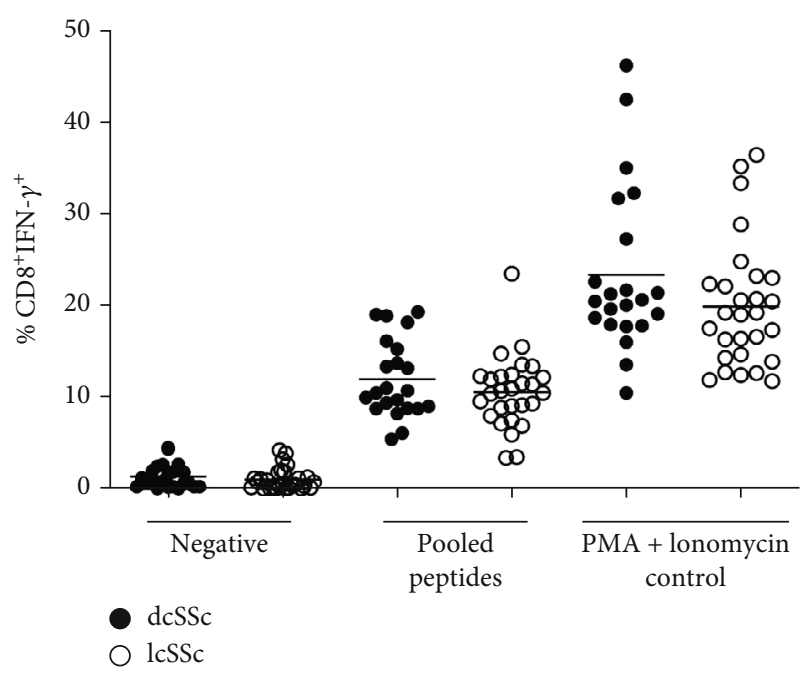

(d)

Figure 4: Percentage of cytokines (IFN- $\gamma$ and IL-2) producing $\mathrm{CD}^{+}(\mathrm{a}, \mathrm{c})$ and $\mathrm{CD}^{+}(\mathrm{b}, \mathrm{d}) \mathrm{T}$ cells following stimulation with media (negative control), pooled peptides derived from DNA topoisomerase-I protein, and PMA ionomycin (positive control) in dcSSc $(n=22)$ and lcSSc $(n=28)$ patients.

2,3 , and 4 contain 12-15 amino acids which should be efficiently processed and presented to $\mathrm{T}$ cells in the context of MHC-II. However, we found that $\mathrm{CD}^{+} \mathrm{T}$ cells from SSc patients reacted to these peptides by secreting cytokines more efficiently than $\mathrm{CD} 4^{+} \mathrm{T}$ cells. This phenomenon has been demonstrated in a study on mice, which showed that long peptides could be presented by the MHC class I molecule [32]. Chen et al. found a high affinity of naturally processed peptides in different amino acids; 9-mer, 10-mer, and 12 mer peptides with human MHC class I molecule (HLAA2.1) [33]. This data suggests that different naturally occurring longer peptides can bind in different conformations to MHC class I molecules. Probst-Kepper et al. previously showed that the pockets $\mathrm{A}$ and $\mathrm{F}$ of HLA-B $* 35: 01$ groove in humans have a high affinity and bind with long peptides over 14 amino acids [34]. Moreover, a study from Australia demonstrated that peptides of $>10$ residues could be recog- nized by MHC class I molecule. They determined the T cell cytotoxicity in the context of HLA-B35 upon stimulation with 11 or 12 amino acid residues peptides derived from the Epstein-Barr virus (EBV) [35]. All these evidences support our finding that $\mathrm{CD} 8^{+} \mathrm{T}$ cells can be triggered by longer peptides and possibly via the MHC class I molecule. Other evidence that supports this hypothesis is that further processing of the 15 mers peptides occurs in the in vitro culture leading to smaller peptides that can be accommodated in the MHC class I groove in the normal fashion [36, 37].

Our study also has some limitations. We only focused on Th1 cytokines (IFN- $\gamma$ and IL-2) whereas other investigators suggested the association of Th2 responses and SSc pathogenesis. Indeed, the Th2 cytokine response, with production of IL-4, IL-10, and TGF- $\beta$, leads to tissue fibrosis $[38,39]$. The small sample size might be an issue for statistical analysis. Future studies with a larger sample size are required to 


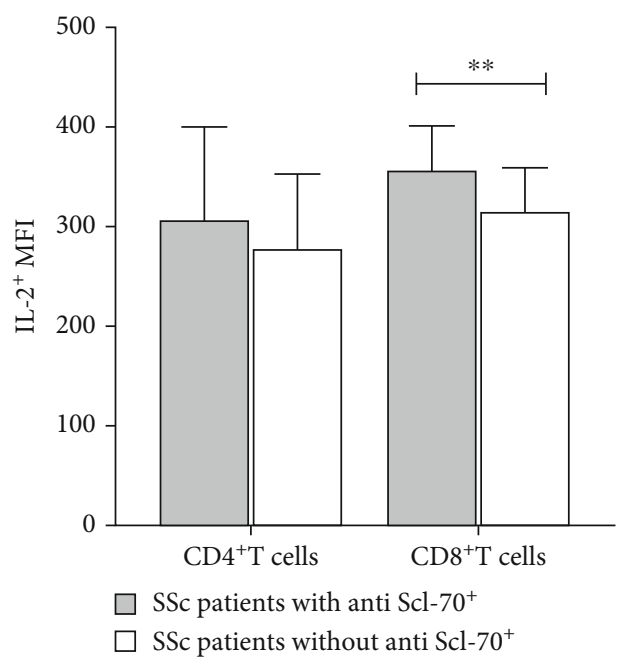

(a)

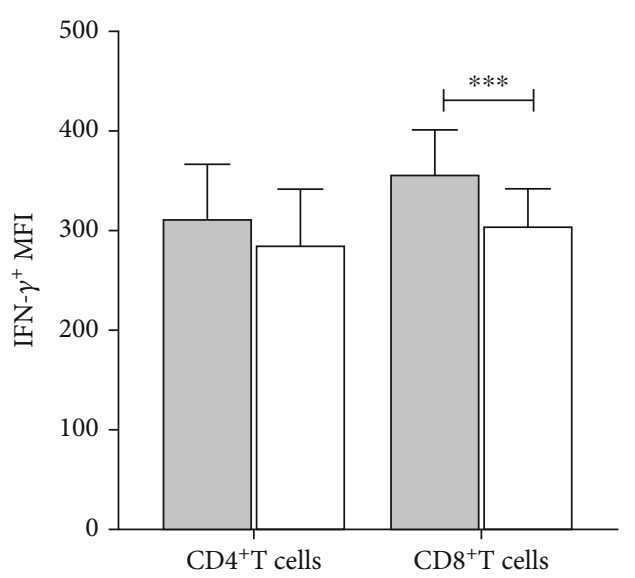

SSc patients with anti Scl- $70^{+}$

$\square$ SSc patients without anti Scl- $70^{+}$

(b)

FIGURE 5: Interleukin-2 (a) and interferon gamma (b) expression of CD4 ${ }^{+}$and $\mathrm{CD}^{+} \mathrm{T}$ cells from SSc patients with and without anti-Scl-70 antibody following stimulation with pooled peptides derived from DNA topoisomerase-I protein. Data was expressed as mean fluorescence intensity (MFI) + SEM of positive cells (Student's $t$-test, $* * p<0.01$ and $* * * p<0.001(n=34$; SSc patients with anti-Scl-70 antibody, $n=16$ ; SSc patients without anti-Scl-70 antibody).

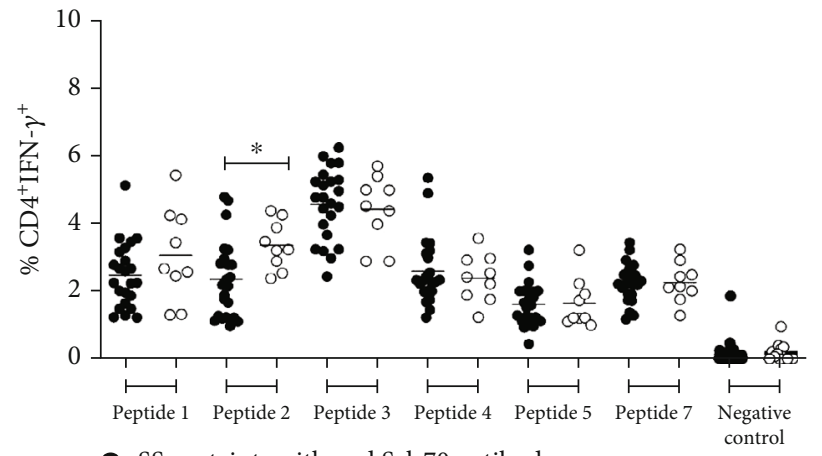

- SSc pateints with and Scl-70 antibody

SSc pateints without and Scl-70 antibody

(a)

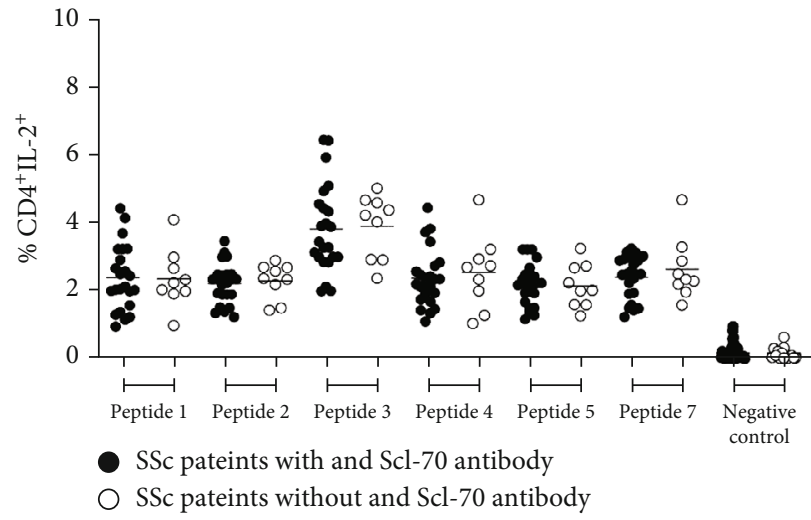

(c)

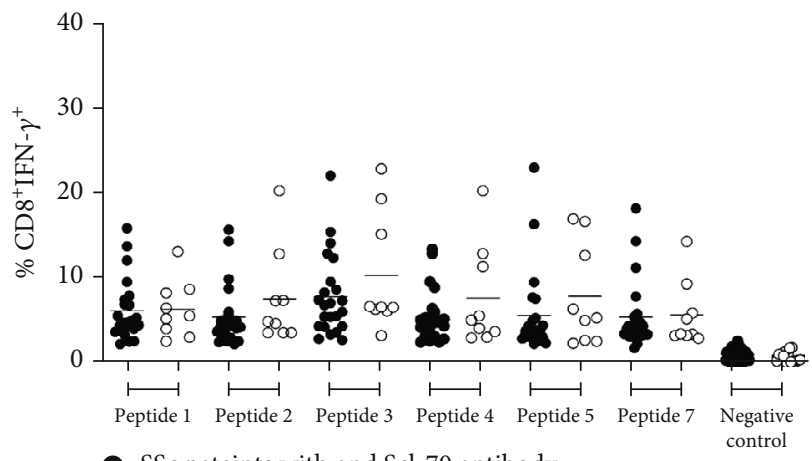

- SSc pateints with and Scl-70 antibody

SSc pateints without and Scl-70 antibody

(b)

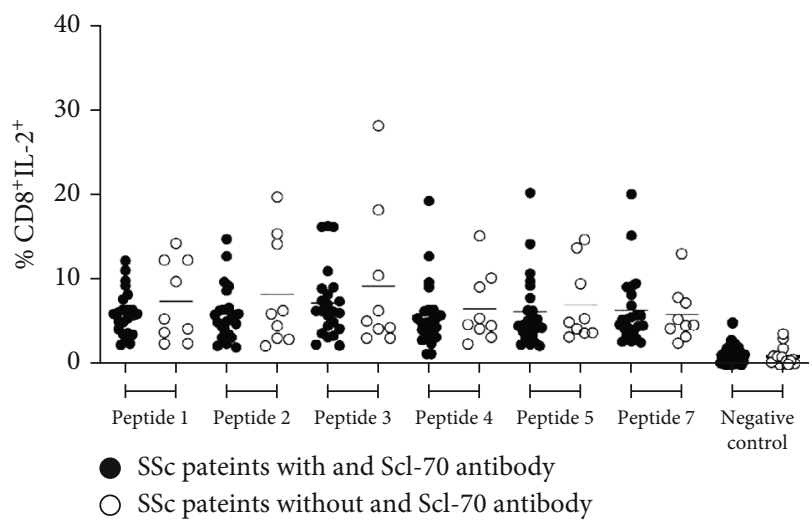

(d)

FIGURE 6: Percentage of cytokine (IFN- $\gamma$ and IL-2) producing $\mathrm{CD}^{+}(\mathrm{a}, \mathrm{c})$ and $\mathrm{CD}^{+}(\mathrm{b}, \mathrm{d}) \mathrm{T}$ cells following stimulation with individual peptides in SSc patients $(n=32)$, (Student's $t$-test, $* p<0.05)$. 
confirm our findings. In addition, determination of both Th1 and Th2 cytokine functions in response to specific peptide stimulation in SSc patients would also be of interest.

\section{Conclusion}

In conclusion, we found increased levels of IFN- $\gamma$ and IL-2 secreting $\mathrm{CD}^{+}$and $\mathrm{CD}^{+}{ }^{+} \mathrm{T}$ cells upon stimulation with the DNA topoisomerase-I peptides. This cytokine production following stimulation with the peptides was restricted to SSc patients and not healthy volunteers. These results amplify the finding of $\mathrm{T}$ cell responses to DNA topoisomerase-I which is an important factor in the pathogenesis of SSc and may be the target of future therapeutic interventions.

\section{Data Availability}

The datasets used and/or analyzed of this study are available from the corresponding author on reasonable request.

\section{Conflicts of Interest}

All authors declare no conflict of interest.

\section{Acknowledgments}

We thank Ms. Ramjai Wichainum for her laboratory assistance and Mrs. Waraporn Sukitawut for her logistical assistance. We also thank Dr. Seiji Okada (Kumamoto University), Dr. Hitoshi Suzuki (Tokyo Seiei College), Dr. Jun Hatamochi (Dokkyo Medical University), and Ms. Ai Nishi (Tokyo University) for their kind advice and technical support in this collaborative study. The study was financially supported by Mahidol University, Thailand, and Grants-inaid for Science Research from the Ministry of Education, Culture, Sport, Science and Technology in Japan (JSPS KAKENHI grant no. 16H05840).

\section{Supplementary Materials}

Supplementary 1. Supplementary Figure 1. Gating strategy. PBMCs from healthy donors (A and B) and SSc patients $(\mathrm{C}$ and $\mathrm{D})$ and stimulated with pooled peptides derived from DNA topoisomerase-I protein then subjected to intracellular staining for $\mathrm{CD} 4+\mathrm{IFN} \gamma+, \mathrm{CD} 4+\mathrm{IL}-2+, \mathrm{CD} 8+\mathrm{IFN} \gamma+$, and CD8+IL-2+ events.

Supplementary 2. Supplementary Figure 2. Percentage of cytokines (IFN- $\gamma$ and IL-2) producing $\mathrm{CD}^{+}$(A and C) and $\mathrm{CD}^{+}(\mathrm{B}$ and $\mathrm{D}) \mathrm{T}$ cells following stimulation with media (negative control) and nonspecific peptide.

\section{References}

[1] G. C. Fanning, K. I. Welsh, C. Bunn, R. Du Bois, and C. M. Black, "HLA associations in three mutually exclusive autoantibody subgroups in UK systemic sclerosis patients," British Journal of Rheumatology, vol. 37, no. 2, pp. 201-207, 1998.

[2] E. J. Kucharz and M. Kopeć-Mędrek, "Systemic sclerosis sine scleroderma," Advances in clinical and experimental medicine:
Official Organ Wroclaw Medical University, vol. 26, no. 5, pp. 875-880, 2017.

[3] M. Kuwana, J. Kaburaki, T. Mimori, Y. Kawakami, and T. Tojo, "Longitudinal analysis of autoantibody response to topoisomerase I in systemic sclerosis," Arthritis and Rheumatism, vol. 43, no. 5, pp. 1074-1084, 2000.

[4] S. Sato, Y. Hamaguchi, M. Hasegawa, and K. Takehara, "Clinical significance of anti-topoisomerase I antibody levels determined by ELISA in systemic sclerosis," Rheumatology (Oxford, England), vol. 40, no. 10, pp. 1135-1140, 2001.

[5] E. C. LeRoy, C. M. Black, R. Fleischmajer et al., "Scleroderma (systemic sclerosis): classification, subsets and pathogenesis," The Journal of Rheumatology, vol. 15, no. 2, pp. 202-205, 1988.

[6] A. Gabrielli, E. V. Avvedimento, and T. Krieg, "Scleroderma," The New England journal of medicine, vol. 360, no. 19, pp. 1989-2003, 2009.

[7] G. Papp, I. F. Horvath, S. Barath et al., "Altered T-cell and regulatory cell repertoire in patients with diffuse cutaneous systemic sclerosis," Scandinavian Journal of Rheumatology, vol. 40, no. 3, pp. 205-210, 2011.

[8] T. R. Radstake, L. van Bon, J. Broen et al., "The pronounced Th17 profile in systemic sclerosis (SSc) together with intracellular expression of TGFbeta and IFNgamma distinguishes SSc phenotypes," PlosOne, vol. 4, no. 6, article e5903, 2009.

[9] P. Fuschiotti, A. T. Larregina, J. Ho, C. Feghali-Bostwick, and T. A. Medsger Jr., "Interleukin-13-producing CD8+ T cells mediate dermal fibrosis in patients with systemic sclerosis," Arthritis and Rheumatism, vol. 65, no. 1, pp. 236-246, 2013.

[10] V. V. Yurovsky, F. M. Wigley, R. A. Wise, and B. White, "Skewing of the CDS + T-cell repertoire in the lungs of patients with systemic sclerosis," Human Immunology, vol. 48, no. 1-2, pp. 84-97, 1996.

[11] M. Kuwana, J. Kaburaki, F. C. Arnett, R. F. Howard, T. A. Medsger Jr., and T. M. Wright, "Influence of ethnic background on clinical and serologic features in patients with systemic sclerosis and anti-DNA topoisomerase I antibody," Arthritis and Rheumatism, vol. 42, no. 3, pp. 465-474, 1999.

[12] M. Kuwana, T. A. Medsger Jr., and T. M. Wright, “T and B cell collaboration is essential for the autoantibody response to DNA topoisomerase I in systemic sclerosis," Journal of Immunology (Baltimore, Md: 1950), vol. 155, no. 5, pp. 2703-2714, 1995.

[13] P. Q. Hu, J. J. Oppenheim, T. A. Medsger Jr., and T. M. Wright, "T cell lines from systemic sclerosis patients and healthy controls recognize multiple epitopes on DNA topoisomerase I," Journal of Autoimmunity, vol. 26, no. 4, pp. 258-267, 2006.

[14] M. Kuwana, T. A. Medsger Jr., and T. M. Wright, “T cell proliferative response induced by DNA topoisomerase I in patients with systemic sclerosis and healthy donors," The Journal of Clinical Investigation, vol. 96, no. 1, pp. 586-596, 1995.

[15] American Rheumatism Association, "Preliminary criteria for the classification of systemic sclerosis (scleroderma)," Arthritis and Rheumatism, vol. 23, no. 5, pp. 581-590, 1980.

[16] P. J. Clements, P. A. Lachenbruch, J. R. Seibold et al., "Skin thickness score in systemic sclerosis: an assessment of interobserver variability in 3 independent studies," The Journal of Rheumatology, vol. 20, no. 11, pp. 1892-1896, 1993.

[17] M. A. Marovich, J. R. Mascola, M. A. Eller et al., "Preparation of clinical-grade recombinant canarypox-human immunodeficiency virus vaccine-loaded human dendritic cells," The Journal of Infectious Diseases, vol. 186, no. 9, pp. 1242-1252, 2002. 
[18] P. P. Lamichhane, K. Boonnak, D. Changsom et al., "H5N1 NS genomic segment distinctly governs the influenza virus infectivity and cytokine induction in monocytic cells," Asian Pacific Journal of Allergy and Immunology, vol. 36, no. 1, pp. 58-68, 2018.

[19] A. C. Pecher, F. Kettemann, E. Asteriti et al., "Invariant natural killer $\mathrm{T}$ cells are functionally impaired in patients with systemic sclerosis," Arthritis Research \& Therapy, vol. 21, no. 1, p. 212, 2019.

[20] A. T. Dantas, S. M. Gonçalves, M. C. Pereira et al., "Interferons and systemic sclerosis: correlation between interferon gamma and interferon-lambda 1 (IL-29)," Autoimmunity, vol. 48, no. 7, pp. 429-433, 2015.

[21] P. Gourh, F. C. Arnett, S. Assassi et al., "Plasma cytokine profiles in systemic sclerosis: associations with autoantibody subsets and clinical manifestations," Arthritis Research \& Therapy, vol. 11, no. 5, p. R147, 2009.

[22] L. M. Diaz-Gallo, C. P. Simeon, J. C. Broen et al., "Implication of $I L-2 / I L-21$ region in systemic sclerosis genetic susceptibility," Annals of the Rheumatic Diseases, vol. 72, no. 7, pp. 1233-1238, 2013.

[23] M. B. Kahaleh and E. C. LeRoy, "Interleukin-2 in scleroderma: correlation of serum level with extent of skin involvement and disease duration," Annals of Internal Medicine, vol. 110, no. 6, pp. 446-450, 1989.

[24] T. V. Kantor, D. Friberg, T. A. Medsger Jr., R. B. Buckingham, and T. L. Whiteside, "Cytokine production and serum levels in systemic sclerosis," Clinical Immunology and Immunopathology, vol. 65, no. 3, pp. 278-285, 1992.

[25] B. W. Needleman, F. M. Wigley, and R. W. Stair, "Interleukin1, interleukin-2, interleukin-4, interleukin-6, tumor necrosis factor alpha, and interferon-gamma levels in sera from patients with scleroderma," Arthritis and Rheumatism, vol. 35, no. 1, pp. 67-72, 1992.

[26] S. Mattuzzi, S. Barbi, A. Carletto et al., "Association of polymorphisms in the IL1B and IL2 genes with susceptibility and severity of systemic sclerosis," The Journal of Rheumatology, vol. 34, no. 5, pp. 997-1004, 2007.

[27] A. Fava, R. Cimbro, F. M. Wigley, Q. R. Liu, A. Rosen, and F. Boin, "Frequency of circulating topoisomerase-I-specific $\mathrm{CD}_{4} \mathrm{~T}$ cells predicts presence and progression of interstitial lung disease in scleroderma," Arthritis Research \& Therapy, vol. 18, no. 1, p. 99, 2016.

[28] C. Prior and P. L. Haslam, "In vivo levels and in vitro production of interferon-gamma in fibrosing interstitial lung diseases," Clinical and Experimental Immunology, vol. 88, no. 2, pp. 280-287, 1992.

[29] G. Valentini, A. Baroni, K. Esposito et al., "Peripheral blood T lymphocytes from systemic sclerosis patients show both Th1 and Th2 activation," Journal of Clinical Immunology, vol. 21, no. 3, pp. 210-217, 2001.

[30] M. Molteni, S. Della Bella, B. Mascagni et al., "Increased interferon-gamma (IFN-gamma) levels produced in vitro by alloactivated $\mathrm{T}$ lymphocytes in systemic sclerosis and Raynaud's phenomenon," Clinical and Experimental Immunology, vol. 116, no. 1, pp. 164-168, 1999.

[31] R. B. Christmann, E. Hayes, S. Pendergrass et al., "Interferon and alternative activation of monocyte/macrophages in systemic sclerosis-associated pulmonary arterial hypertension," Arthritis and Rheumatism, vol. 63, no. 6, pp. 1718-1728, 2011.
[32] J. Stevens, K. H. Wiesmüller, P. Walden, and E. Joly, "Peptide length preferences for rat and mouse MHC class I molecules using random peptide libraries," European Journal of Immunology, vol. 28, no. 4, pp. 1272-1279, 1998.

[33] Y. Chen, J. Sidney, S. Southwood et al., "Naturally processed peptides longer than nine amino acid residues bind to the class I MHC molecule HLA-A2.1 with high affinity and in different conformations," Journal of Immunology (Baltimore, Md: 1950), vol. 152, no. 6, pp. 2874-2881, 1994.

[34] M. Probst-Kepper, H. J. Hecht, H. Herrmann et al., "Conformational restraints and flexibility of 14-meric peptides in complex with HLA-B $* 3501$," Journal of Immunology (Baltimore, Md: 1950), vol. 173, no. 9, pp. 5610-5616, 2004.

[35] J. M. Burrows, M. J. Bell, R. Brennan, J. J. Miles, R. Khanna, and S. R. Burrows, "Preferential binding of unusually long peptides to MHC class I and its influence on the selection of target peptides for T cell recognition," Molecular Immunology, vol. 45 , no. 6, pp. 1818-1824, 2008.

[36] S. Matsumura, H. Kita, X.-S. He et al., "Comprehensive mapping of HLA-A $0 * 201$-restricted CD8 T-cell epitopes on PDC-E2 in primary biliary cirrhosis," Hepatology, vol. 36, no. 5, pp. 1125-1134, 2002.

[37] Y. Xu, S. Wasnik, D. J. Baylink, E. C. Berumen, and X. Tang, "Overlapping peptide library to map Qa-1 epitopes in a protein," Journal of Visualized Experiments, vol. 130, no. 130, 2017.

[38] J. Baraut, L. Michel, F. Verrecchia, and D. Farge, "Relationship between cytokine profiles and clinical outcomes in patients with systemic sclerosis," Autoimmunity Reviews, vol. 10, no. 2, pp. 65-73, 2010.

[39] A. T. Dantas, A. R. Almeida, M. Sampaio et al., "Different profile of cytokine production in patients with systemic sclerosis and association with clinical manifestations," Immunology Letters, vol. 198, pp. 12-16, 2018. 